\author{
Józef Kąś \\ Wydział Polonistyki UJ \\ Katedra Historii Języka i Dialektologii \\ ORCID: 0000-0003-1519-6088; e-mail: jozef.kas@uj.edu.pl
}

\title{
Zmiany w gwarowym systemie leksykalnym a praktyka leksykograficzna
}

\begin{abstract}
Abstrakt: W artykule omawiane są: struktura gwarowego systemu leksykalnego oraz zmiany w tym systemie dokonujące się w wyniku oddziaływania słownictwa ogólnopolskiego i zmian cywilizacyjno-społecznych na wsi. Strukturę systemu leksykalnego tworzy słownictwo wspólne z polszczyzną ogólną (słownictwo współsystemowe, kulturowe i interferencyjne) oraz słownictwo dyferencyjne. W zakresie zmian wskazuje się na zapożyczenia nazw razem z przyjmowaniem nowych elementów kultury, na tworzenie neologizmów i neosemantyzmów oraz na przesuwanie leksemów do słownictwa biernego.
\end{abstract}

Słowa kluczowe: gwara, interferencja leksykalna, słownictwo czynne i bierne.

\begin{abstract}
Changes in the lexical system of dialects versus the lexicographic practice. The paper discusses the structure of the lexical system of dialects, and the respective changes taking place under the influence of the national language as well as the civilizational and social changes in rural areas. The structure of the system consists of vocabulary shared with the literary language (intersystemic, cultural, and interferential vocabulary), as well as differential vocabulary. With respect to changes, the paper indicates borrowings of names which coexist with borrowings of new elements of culture, emergence of neologisms and neosemantisms, and a shift of lexemes from active to passive vocabulary.
\end{abstract}

Keywords: dialect, lexical interference, active and passive vocabulary.

Świadomość dokonujących się gwałtownie zmian w gwarowych systemach leksykalnych jest dosyć powszechna, niemniej jednak wiedza na ten temat jest uproszczona. Sprowadza się ona zasadniczo do dwóch głównych zjawisk: zanikania tradycyjnego słownictwa gwarowego oraz przejmowania z polszczyzny ogólnej konkurencyjnego słownictwa ogólnopolskiego. Zjawisko pierwsze jest prostą konsekwencją przemian cywilizacyjnych na współczesnej wsi i zanikania w związku z tym przedmiotów i pojęć związanych z dawnymi formami gospodarowania i warunkami życia, zaś zjawisko drugie $\mathrm{z}$ wdzierającą się na wieś ogólnie pojętą nowoczesnością zacierającą dawne różnice między wsią i miastem. W skrócie rzecz można ująć następująco: uchodzi stare - wchodzi nowe. Owszem, ale to przecież istota zmian leksykalnych od najdawniejszych czasów. Najbardziej interesujące są w tym procesie szczegóły.

Omawiane w niniejszym artykule procesy są w większości znane. Stąd też nie chodzi tu zasadniczo o odkrywanie nowości, a jedynie o uporządkowanie znanych wcześniej 
prawidłowości i logiczne ich uszeregowanie z punktu widzenia działania systemu leksykalnego.

Jak wiadomo, każdy system jest zbiorem jednostek wzajemnie powiązanych z sobą, szachujących się. Miejsce i jakość jednostki są zatem warunkowane przez pozostałe jednostki. System leksykalny jest najbardziej otwartym podsystemem języka, co skutkuje jego nieustanną dynamiką. System ten nigdy nie pozostaje w stagnacji, gdyż działają nań systemy ościenne (innych gwar, polszczyzny ogólnej), a gdyby nawet wyobrazić sobie system izolowany geograficznie i kulturowo, to zmiany dokonują się wewnątrz niego, np. powstają neologizmy, neosemantyzmy jako następstwa zmian cywilizacyjnych w obrębie tak izolowanej grupy społecznej.

\section{Stan}

Przed omówieniem dynamicznego stanu gwarowego systemu leksykalnego przyjrzyjmy się jego zasobowi - dla ułatwienia - w układzie statycznym oraz w relacji do słownictwa ogólnopolskiego (por. rys. 1).

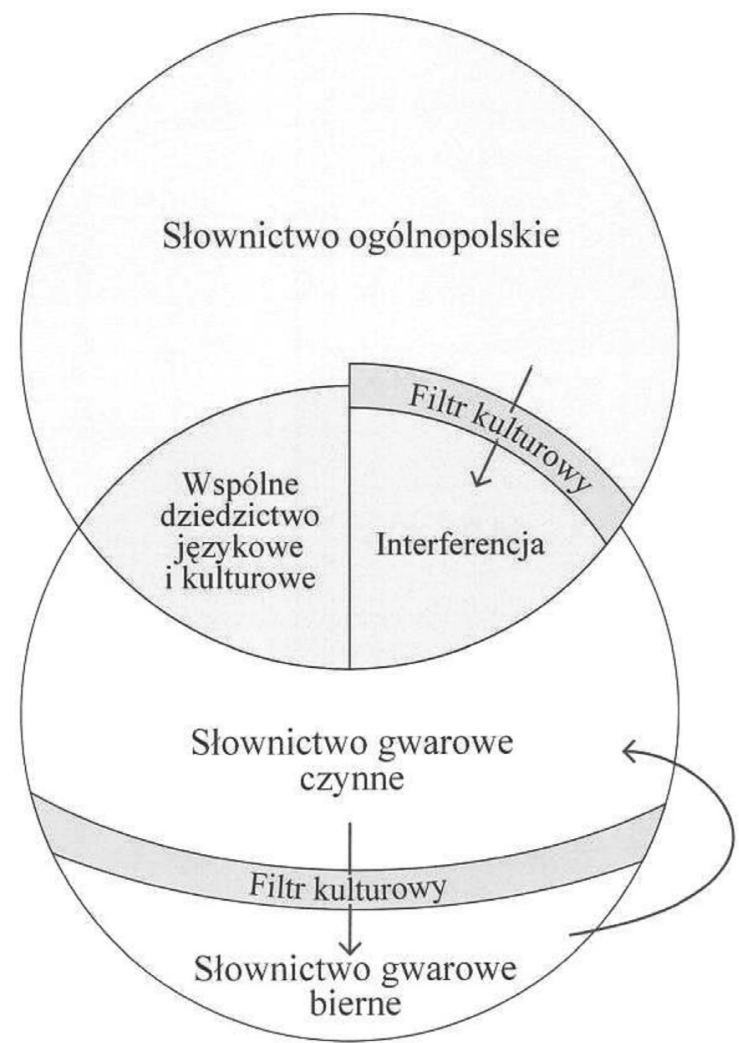

Rys. 1. Relacje słownictwa gwarowego i ogólnopolskiego 
Tab. 1. Gwarowy system leksykalny

\begin{tabular}{|c|c|c|}
\hline \multirow{2}{*}{$\begin{array}{c}\text { Slownictwo } \\
\text { wspólne }\end{array}$} & $\begin{array}{c}\text { Slownictwo wspólsystemowe } \\
\text { (dziedzictwo wspólnoty językowej) }\end{array}$ & $\begin{array}{c}\text { glowa, noga, woda, drzewo, pies, } \\
\text { niebo, widzié, chodzić, mieć }\end{array}$ \\
\cline { 2 - 3 } & $\begin{array}{c}\text { Slownictwo kulturowe } \\
\text { (dziedzictwo wspólnoty językowej } \\
\text { i kulturowej - typowe dla kultury wiejskiej) }\end{array}$ & $\begin{array}{c}\text { widly, grabie, plug, wóz, kosa, } \\
\text { siano, jarzmo, niedziela, Wigilia }\end{array}$ \\
\cline { 2 - 3 } & $\begin{array}{c}\text { Slownictwo interferencyjne } \\
\text { (wpływy polszczyzny ogólnej) }\end{array}$ & telewizor, wersalka, pralka \\
\hline $\begin{array}{c}\text { Slownictwo } \\
\text { dyferencyjne }\end{array}$ & $\begin{array}{c}\text { Odmienne formalnie lub semantycznie } \\
\text { (zob. tab. 2.) }\end{array}$ & $\begin{array}{c}\text { kohut, fugowiny, filoflos, } \\
\text { redykotka, zescekać }\end{array}$ \\
\hline
\end{tabular}

Rysunek obrazuje dwa główne konkurujące z sobą i wpływające na siebie systemy leksykalne: ogólnopolski i gwarowy. Rozpatrywane tu relacje i wyciągane wnioski przekładają się bezpośrednio na praktykę leksykograficzną. Do rozstrzygnięcia pozostaje tylko oszacowanie naszych możliwości praktycznych w stosunku do postulatów teoretycznych.

$\mathrm{Na}$ zaprezentowanym rysunku interesuje nas okrąg dolny, ukazujący gwarowy system leksykalny. Wyróżniamy w nim dwie grupy słownictwa: słownictwo wspólne z polszczyzną i słownictwo dyferencyjne. Słownictwo pierwszej grupy nie jest jednorodne, bo dadzą się tu wydzielić trzy podgrupy: słownictwo współsystemowe, słownictwo kulturowe i słownictwo interferencyjne. Stan ten przedstawia tabela 1.

\section{Słownictwo wspólne z polszczyzną ogólną}

\subsection{Słownictwo współsystemowe jest dziedzictwem dawnej wspólnoty językowej} na różnych jej poziomach czasowych (od prasłowiańszczyzny po ostatnie związki mniejszych grup plemiennych przed ostatnimi ruchami migracyjnymi). W praktyce słownikarskiej, przy ograniczeniu słownika do leksyki „typowo gwarowej” słownictwo to jest odrzucane w pierwszej kolejności.

1.2. Słownictwo kulturowe ${ }^{1}$ jest dziedzictwem dawnej wspólnoty kulturowej, tzn. świadczy o wspólnym dorobku kulturowym przed ruchami migracyjnymi, tak w zakresie

\footnotetext{
${ }^{1}$ Pojęcia tego używa też H. Kurek, jednak w zdecydowanie odmiennym znaczeniu. Pisze ona: „W systemie komunikacyjnym każdej wspólnoty kulturowej, a zwłaszcza wiejskiej, istnieją pewne zjawiska językowe niespotykane na innych terenach, charakterystyczne wyłącznie dla tej wspólnoty. Jednostki te, mające swoistą treść tylko na określonym, niewielkim obszarze, przekazywane z pokolenia na pokolenie, świadczą o silnym związku ich użytkowników z najbliższą «małą ojczyzną» (...). W wiejskim obszarze językowo-kulturowym za «leksemy kulturowe» uznać zatem można między innymi te jednostki leksykalne, które charakterystyczne są wyłącznie dla «(...) mikropola semantycznego» lokalnej społeczności kilku lub kilkunastu wsi. Najczęściej są to archaizmy słownikowe typowe dla obszarów peryferyjnych, izolowanych terytorialnie" (por. Kurek 2003, 135).

Przytoczony opis tego typu słownictwa bardziej jednak odpowiada tradycyjnie rozumianym regionalizmom lub gwaryzmom.
} 
kultury materialnej, jak i duchowej. Słownictwo to nazywa typowe dla środowiska wiejskiego czynności i narzędzia pracy. Stąd też nawet w słownikach dyferencyjnych wyrazy tego typu są obecne, bo bez nich nie sposób mówić o kulturze wiejskiej. Nie dziwi zatem fakt, że po dyskusji nad koncepcją ogólnopolskiego Słownika gwar polskich słownictwo to, aczkolwiek niedyferencyjne, zostało włączone do słownika zasadniczo dyferencyjnego (por. Karaś 1960).

1.3. Słownictwo interferencyjne to z kolei warstwa najnowszych pożyczek z polszczyzny ogólnej, będąca efektem przenikania na wieś wielowymiarowej „nowoczesności". Trudno wskazać całkowicie ostre kryteria, według których jedne wyrazy tej warstwy winny być włączane do słownika, inne zaś odrzucane. Do dyspozycji mamy następujące kryteria: stopień powszechności znajomości leksemu, frekwencję wyrazu w tekstach, stopień zakorzenienia się wyrazu w mowie mieszkańców wsi. Ostatnie kryterium wydaje się najwłaściwsze, choć i tak arbitralne. W tym miejscu pouczająca jest pewna historia. W roku 2005, kiedy rozpoczynałem pracę nad Stownikiem gwary $i$ kultury podhalańskiej, pan Józef Pitoń - jeden z najznakomitszych twórców regionalnych, zapytał mnie, czy słowo komórka 'telefon komórkowy' też znajdzie się w słowniku. Ponieważ telefon taki był wówczas na wsi wielką rzadkością, odparłem iż komórka nie wrosła jeszcze w ziemię podhalańską, więc trzeba by ją pominąć. Dziś, kiedy nawet babcie pytlują przez komórkę, należy ją uwzględnić. Owo powszechne pytlowanie stało się zresztą dla innej znaczącej dla Podhala postaci - Wandy Czubernatowej - podstawą do stworzenia neologizmu pytlorka, obok konkurencyjnej przyuśnicy.

\section{Słownictwo dyferencyjne}

Kryterium dyferencyjności to najistotniejsze z kryteriów stosowanych w selekcji materiału leksykalnego zamieszczanego w słownikach gwarowych. Sprowadza się ono do wybierania słownictwa specyficznego dla gwary, a tym samym odrzucania słownictwa obecnego zarówno w gwarze, jak i w polszczyźnie ogólnej. W efekcie stosowania tego kryterium wydziela się słownictwo zróżnicowane w stosunku do polszczyzny ogólnej pod względem semantycznym i formalnym. Jest to kryterium tyleż naukowe, co i intuicyjne. Intuicyjne, bo stosowane od dawna po dzień dzisiejszy przez rzesze leksykografów-amatorów, entuzjastów słownictwa gwarowego. Z drugiej jednak strony słownictwo notowane intuicyjnie da się objąć ścisłym, naukowym narzędziem. Jest nim ocena konkretnego wyrazu pod kątem stopnia podobieństwa z odpowiednią jednostką z systemu leksykalnego polszczyzny. Schematycznie przedstawia to tabela 2 (przykłady wyrazów gwarowych pochodzą z mojej rodzinnej gwary orawskiej oraz z gwary podhalańskiej). 
Tabela. 2. Gwarowe słownictwo dyferencyjne według stopnia podobieństwa w stosunku do zasobu polszczyzny ogólnej

\begin{tabular}{|c|c|c|c|c|}
\hline Forma & Taka sama & $\begin{array}{l}\text { Różnice } \\
\text { morfologiczna }\end{array}$ & $\begin{array}{l}\text { Zleksykazlizowana } \\
\text { różnica fonetyczna }\end{array}$ & Całkiem inna \\
\hline To samo & $\begin{array}{l}\text { niebo } \\
\text { woda } \\
\text { owca }\end{array}$ & $\begin{array}{c}\text { rybiorz 'rybak' } \\
\text { trot 'trociny' } \\
\text { skrzipki 'skrzypce' } \\
\text { kosiec 'kosiarz' } \\
\text { bratówka 'bratowa' } \\
\text { beretka 'beret' }\end{array}$ & $\begin{array}{l}\text { kohut 'kogut' } \\
\text { wyźreć 'wyjrzeć' } \\
\text { gulka 'kulka' } \\
\text { sweder 'sweter' } \\
\text { husiać 'huśtać' }\end{array}$ & $\begin{array}{c}\text { śkrypta 'zeszyt' } \\
\text { sybáłka 'zapałka' } \\
\text { plekać 'karmić } \\
\text { piersią' } \\
\text { aspon 'przynajmniej' } \\
\text { kutac 'pogrzebacz' } \\
\text { pettnik 'flisak' } \\
\text { śkoryca 'cynamon' }\end{array}$ \\
\hline Węższe & $\begin{array}{c}\text { scyt }(\mathrm{w} \text { wozie }) \\
\text { pozycyć (komu) } \\
\text { chatupa }\end{array}$ & $\begin{array}{c}\text { kuchnisto 'kucharka } \\
\text { wynajęta do obsługi } \\
\text { wesela' } \\
\text { zioberko 'żeberko } \\
\text { w kaloryferze' }\end{array}$ & $\begin{array}{l}\text { warztat 'warsztat } \\
\text { tkacki' }\end{array}$ & deska 'narta' \\
\hline Szersze & $\begin{array}{c}\text { pytać + 'prosić' } \\
\text { koło + 'rower' } \\
\text { wiyrch + 'wierzch' } \\
\text { izba + 'dom' } \\
\text { baranek + } \\
\text { 'karakuły' } \\
\text { butka + 'pąk' }\end{array}$ & & $\begin{array}{c}\text { hruby + 'bogaty' } \\
\text { kilometer + 'słup } \\
\text { oznaczający odcinek } \\
1 \text { kilometra' }\end{array}$ & $\begin{array}{c}\text { deska }+ \text { 'deska } \\
\text { o grubości } 5 / 4 \text { cala' }\end{array}$ \\
\hline $\begin{array}{l}\text { Calkiem } \\
\text { inne }\end{array}$ & $\begin{array}{l}\text { woźnica* } \\
\text { medyk* } \\
\text { rektor* } \\
\text { rosól* }\end{array}$ & $\begin{array}{c}\text { ozprowka } \\
\text { 'opowiadanie o treści } \\
\text { zwykle zmyślonej; } \\
\text { bajka, baśń': }\end{array}$ & $\begin{array}{c}\text { gorole }+ \text { 'czerwony } \\
\text { fałd skóry zwisający } \\
\text { pod szyją indyka } \\
\text { i pod dziobem } \\
\text { koguta' }\end{array}$ & $\begin{array}{l}\text { śmigla* } \\
\text { piecka* } \\
\text { redykotka* }\end{array}$ \\
\hline
\end{tabular}

*woźnica - 'zamykany drzwiczkami otwór w suficie kurnej chaty, którym uchodził dym z otwartego paleniska w czarnej izbie’

*medyk - 'z uznaniem o człowieku mającym szczególne zdolności techniczne, umiejącym wymyślić wiele rozwiązań technicznych i potrafiącym zrealizować je osobiście; złota rączka'

* rektor - 'organista; dawno w szkole nauczał religii, czasem też innych przedmiotów'

*rosót - 'bardzo mocno nasolona woda, używana do konserwacji mięsa i słoniny po zabiciu świni lub do konserwacji oscypków; właściwe stężenie soli w roztworze sprawdza się przez wrzucenie do niego świeżego jajka (rzadziej ziemniaka) - w takim roztworze jajko ma nie tonąć'

*śmigla - 'płaski, wykonany z mocnego, zwykle jesionowego drewna, szczebel w drabinie wozu, wzmacniający jej konstrukcję (zwykle 3, 4 sztuki); też: płaski, ozdobnie wykończony (frezowany lub nawet rzeźbiony) szczebel w drabinach używanych do odświętnych wyjazdów, np. do ślubu'

*redykołka - 'mały serek w kształcie zwierzęcia (np. jelenia, koguta, barana, kaczki itp.), parzenicy, wyrabiany w szałasie z sera owczego, dawany jako prezent gościom odwiedzającym szałas, zwłaszcza dzieciom; dawany też przez bacę właścicielom owiec, pannom jako prezent po jesiennym redyku'

*piecka - 'dawno: ukośna część komina nad sufitem, tłumiąca iskry (w kominie wyprowadzonym tylko na strych, nie nad dach, jak współcześnie’ 


\section{Zmiany}

Rozpatrzmy dwie zasadnicze sytuacje: wchodzenie „nowego” i wychodzenie „starego" z systemu leksykalnego. Wbrew pozorom łączy je jedna bardzo istotna cecha. Obie te sytuacje są konsekwencjami zachodzących zmian cywilizacyjnych w rzeczywistości pozajęzykowej. Można powiedzieć, że zarówno „nowe”, jak i „stare” przechodzi przez filtr kulturowy (szerzej zob. Kąś 1994, 38-51). Filtr kulturowy rozumiany jest tu szeroko - to coś więcej niż nowe elementy kultury materialnej, to także wartościowanie gwary wywołujące przełączanie kodów nie tylko w kontaktach z rozmówcami obcymi. Kod niegwarowy wybierany jest też $\mathrm{w}$ kontaktach $\mathrm{z}$ osobami $\mathrm{z}$ tego samego kręgu kulturowo-językowego, nawet $\mathrm{z}$ rówieśnikami, jeśli wymaga tego obrona własnego prestiżu: Musze rozmawiać z koleżanka po polsku (tj. nie gwarą), żeby se nie pomyślała, że jestem zacofana - mówi młoda Orawianka o rozmowach z sąsiadką (!), znająca gwarę, ale posługująca się nią tylko w domu.

\section{Sytuacja pierwsza - wchodzi „nowe”}

\subsection{Nowy leksem wchodzi do systemu gwarowego w miejsce zajęte przez lek- sem gwarowy}

Wydawałoby się, że oczywista w tej sytuacji rywalizacja „starego" i „nowego" winna się skończyć wypchnięciem dotychczasowego leksemu z systemu albo przynajmniej zepchnięciem go na peryferie. Rzeczywiście, najczęściej tak się dzieje, a przejawem tego procesu jest „starzenie” się leksemu gwarowego, tj. jego znikanie z systemu młodszych pokoleń. Obserwuje się tu jednak również bardzo interesujące zjawisko współistnienie „starego" i „nowego”, a to dzięki specyfikacji semantycznej. Cecha starego desygnatu, dotychczas niedystynktywna, w konfrontacji $\mathrm{z}$ desygnatem nowym staje się nagle cechą odróżniającą. Tak tworzą się dublety wyrazowe, kłopotliwe dla badacza i słownikarza, które wydają się synonimami. Synonimii przeczy jednak prawo ekonomii językowej. Porównaj pary:

plot - tradycyjny, z drewnianymi sztachetami: ogrodzenie - nowe, metalowe;

wrotka 'furtka w tradycyjnym płocie': bramka 'furtka w nowym ogrodzeniu';

stulik 'szuflada w dawnych meblach, np. w kaśni': sufloda 'szuflada w meblach nowych, np. w biurku'.

Efekt tego procesu przedostał się nawet do polszczyzny ogólnej w parze portki 'podhalańskie, sukienne spodnie będące częścią stroju regionalnego': spodnie

1.2. Nowy leksem wchodzi do systemu gwarowego w miejsce zajęte przez dwa lub więcej leksemów gwarowych

Niesymetryczność układu wywołuje niwelowanie niektórych semów znaczeń leksemów gwarowych. Ciekawych obserwacji dostarcza tu rodzina sztachet w gwarze orawskiej. Do tej rodziny zaliczają się nazwy: tyniorka [\| tynina, tylina, tyniok], drandź [\| dranć, drandzia], scebel, śteka [\| śtek, śtekla], śtacheta.

Współcześnie zwycięża zdecydowanie śtacheta, i to nie tylko dlatego, że wspierana jest przez ogólnopolską sztachetę. Wypadanie z systemu pozostałych określeń to właś- 
nie efekt niwelowania semów szczegółowo dookreślających rożne rodzaje sztachet kształt, sposób wykonania:

tyniorka to 'starannie odłupana z klocka drewna szczapa, przypominająca cienką deseczkę; najlepsze były tyniorki łupane NA MACKĘ, tj. wzdłuż słojów (promieniście, podobnie jak łupie się gonty), a nie w poprzek, przez co nie poddawały się łatwo paczeniu';

drandź to 'sztacheta łupana z prostego klocka bez sęków, o przekroju kwadratu lub prostokąta; współcześnie też cięta na pile mechanicznej’;

scebel to 'okrągła sztacheta wykonana ze ściętego smreczka' (smreczków takich było sporo w gęstych młodnikach, które należało przerzedzać);

śteka z kolei jest najbliższym odpowiednikiem współczesnej śtachety, a różnica formalna wynika z pośredniego lub bezpośredniego zapożyczenia do gwary.

\subsection{Nowy leksem wchodzi do systemu gwarowego $w$ miejsce puste}

Obserwuje się tu trzy sposoby reagowania systemu:

1.3.1. Zapożyczanie pojęcia i nazwy, np.: mikser, telewizor, wersalka, komórka. W pełnym słowniku gwarowym takie nazwy winny się znaleźć, by można było udokumentować aktualny stan gwary i kultury danego regionu. Przy okazji warto zwrócić uwagę na najczęściej używaną formę pytań przy gromadzeniu danych dotyczących kultury wiejskiej. Najczęściej zadajemy nieświadomie pytania w czasie przeszłym (co się jadło na Wigilię, jak przebiegały żniwa, jak przepowiadano pogodę itp.) i tym samym eliminujemy ze słownika współczesność.

1.3.2. Tworzenie neologizmów, np.:

pytlorka, przyuśnica 'telefon komórkowy';

smarkot, smyrfacka, smyrfok, smyrac 'smartfon';

poziyradło, telepoziyradło, betoniara, gapidło, ogłupiac, telegapidło, teleoglupiac, telepytel, telepudto, telebujac, gulgot ' $\mathrm{z}$ negatywnym nacechowaniem emocjonalnym o telewizorze';

parzok 1. 'naczynie do zaparzania kawy' 2. 'elektryczny lub opalany drzewem kocioł do parowania jedzenia dla świń';

sianozbiyrok 'maszyna do mechanicznego zbioru siana, przypinana za traktorem';

struzywiórek 'żartobliwie o ludowym artyście rzeźbiarzu';

lypiglinek 'żartobliwie o ludowym artyście lepiącym figurki z gliny’;

usypiac 'anestezjolog';

medyjok 'dziennikarz, zwłaszcza telewizyjny';

zabawiac 'człowiek zabawiający gości, uczestników imprezy'.

W praktyce leksykograficznej problemem jest odróżnienie neologizmu już utrwalonego, tj. rozpowszechnionego wśród użytkowników gwary od neologizmu rzadkiego, tj. okazjonalizmu, indywidualizmu. Decyzja o włączeniu lub odrzuceniu takich wyrazów ze słownika zależy oczywiście od charakteru samego słownika. W słowniku ograniczonym dla okazjonalizmów nie ma miejsca, ale w słowniku pełnym - owszem. Nowe wyrazy rzadkie, okazjonalizmy, indywidualizmy pokazują bowiem z jednej strony mechanizmy powstawania w systemie nowego słownictwa i są dowodem żywotności gwary, zaś z drugiej - dokumentują historię jego wchodzenia do systemu. Kwestia neologizmów jest fragmentem szerszego problemu leksykologicznego i leksykograficznego, mianowicie problemu wyrazów rzadkich (por. Wyderka 2007; Pelcowa 2007). 
Neologizmy odzwierciedlają aktualne mechanizmy słowotwórcze, natomiast zachowane, dawniejsze wyrazy rzadkie wskazują na ich etymologię, tzn. na dawne rdzenie oraz na zasób dawnych formantów, których czytelność może być już współcześnie zatarta. Niska frekwencja takich wyrazów nie przekreśla zasadności włączenia ich do słownika.

1.3.3. Tworzenie neosemantyzmów, np.:

pudto 'telewizor';

sprzagacka 'tworzenie koalicji przez partie polityczne': I zaś momy rechot $i$ wselinijakom hipkacke pokrony obiora nasýk wiyrchowników. Neji coz cłek pocnie? Jes wej tak $i$ bez te pore tyźni bedzie. Nastol tyz cas sprzongacek. Tyn sie sadowi tutok, tamtyn tamok. Sýćkim zaś ponoć na sercýskak siedzi nase pospólne dobro. Dyć niekzeby ta, choć po mojemu, takowe furganie to tu, a zaś tu, nie barz przistoji rzetelnymu chtopisku (Hodorowicz 2008, 18); porównać trzeba też znaczenie pierwotne: 'ustna umowa między dwoma gospodarzami dotycząca wspólnej orki i innych ciężkich prac wiosennych': By sie nie podzioło, jako w rodnyj Bukowinie. A rzec sie miała pół sta roków nazod, kie do sprzongacki wziyno sie dwók rzetelnyk gazdów: Skiba i Lach. Sprzyngli sie i pocyni orać pospotu. Telo ino, ze pogoda wikrowata i tak jakosi sie dzioło, ze świyciyto, kie byli na zogónie Skiby, zaś kie u Lacha, to padto na psote. Zeźlyło to Lacha i pocon Skibie wymówke cýnić. Wte ustysot: „Kie pogoda jako sýba, orze Skiba. Kie kapie z dacha, orzymy u Lacha”. I tak sie skóńcyła ta sprzongacka. Jakosi ta samostajyncý orzbe dopucyli. Jakiesi ta zbórki tyz mieli. Nodyć jak było, tak było, kozdy ś nik ino za sie odpowiadat (Hodorowicz 2008, 74-75);

sprzazka 'koalicja';

becólka 'rodzaj oscypka bez charakterystycznych stożkowych końcówek, wyrabianego w domu z mleka krowiego': Becółke sie robi tak samo, jak oscypek, ino, ze becółka jes mniyjso, tak o połowe, ale tyz sie wyndzi jak oscypek. Ale niektorzi lubiom tyz nie wyndzony, bioły jak syr, to takie tyz robime (Kąś 2015, 216 [synonimy: gnotecek, gołka, klocek, kłotek, pucok, scypek, społtek, społtek krówski, syrek góralski, syr gazdowski]).

\section{Sytuacja druga - uchodzi ,stare"}

\subsection{Zanikanie realiów, praktyk}

Jest to powszechnie znane zjawisko będące następstwem zmieniających się realiów cywilizacyjnych na wsi. Znikają bogate w terminologię pola semantyczne i pola wyrazowe, np. pole z zakresu tkactwa, narzędzi i ręcznych prac rolnych, budownictwa drewnianego (pozostaje natomiast terminologia dotycząca więźby dachowej), stroju ludowego itd. Wyrazy z tych pól tematycznych stają się stopniowo właściwe tylko najstarszym użytkownikom gwary, a ostatecznie przechodzą do zasobu biernego. Konsekwencjami tych zmian są:

\subsubsection{Zanikanie cech semantycznych}

Wyraz pozostaje, ale znaczenie się rozmywa - potwierdzają to dane z przeprowadzonej ankiety na temat znaczenia wyrazu Lach:

'mieszkaniec okolic Limanowej handlujący prosiętami' (to pierwotne znaczenie gwarowe); 
'mieszkaniec okolic Limanowej';

'handlarz prosiętami';

'prosię'.

Podobnie w przypadku określenia kiscone mlyko 'kwaskowate mleko uzyskane przez pozostawienie $\mathrm{w}$ drewnianej dzieży słodkiego mleka aż do jego skwaśnienia, a następnie dolewanie nowych porcji świeżego mleka (nawet przez kilka miesięcy) wraz z systematycznym wypijaniem zawartości dzieży; przez to mleko zachowuje jednakową konsystencję (w przeciwieństwie do kwaśnego mlyka, w którym wyraźnie wytrąca się serwatka); mleko uważane za znakomity napój w czasie upałów. Termin o ginącym pierwotnym znaczeniu (określenia kiscone mlyko i kwaśne mlyko są używane zamiennie w różnych rodzinach na oznaczenie 'zsiadłego mleka'), a to z tego powodu, że współcześnie nikt nie przechowuje takiego mleka przez kilka miesięcy i nie dolewa kolejnej porcji do poprzedniej (taką informację znajdujemy jeszcze u W. Matlakowskiego (1901, 90))': Jak było cým omaścić, to sie jadło grule omascone spyrkom, pokrajanom $i$ upieconom na skwarki. Pote sie jadto grule piecone $w$ popiele. Trza wiedzieć, ze grule sie skrobało, a nie obiyrało jak dziś, coby ino ciyniućko skórecka z grulki ślazła, choć i ta tupinka sła krowom. Grule jedli z mlykem kwaśnym i kisconym, casym ze słodkim. Róźnica miyndzý mlykem kwaśnym i kisconym była ta, ze mlyko kwaśne to byto świyzo zsiedniynte, choć juz bez śmietany. Takie mlyko dato sie tyzkom krojić. Reśte mlyka kwaśnego ślywało sie do dziyzki, takiyj drewnianyj becółki bez wiyrchu, co stoła zawse w chłodzie. I w tyj dziyzce mlyko sie kiscyło. Kis - znacyt po góralsku kwas. Takiego mlyka sie napić, to cłekowi mogło kufe na bok skryncić, ale ono byto okropnie dobre na goronc. Nim jeś sie wnet napiyt (Gutt-Mostowy 1998, 59; [synonimy: kisconka, kisone mlyko, skiste mlyko; Kąś 2017, 443-444]).

\subsubsection{Przejście do grupy ekspresywizmów, np.:}

koromysto 'grat zawadzający komuś' (weź to koromysło stąd - mowa o monitorze komputera; znaczenie pierwotne: 'drewniane nosidło do noszenia na barkach wiader z wodą');

gacie 'spodnie' (znaczenie pierwotne: 'dolna część męskiej bielizny, z długimi nogawkami, dawniej szyte z pacześnego płótna, współcześnie kupowane - bawełniane; kalesony)'; nieistotnym staje się materiał oraz to, czy jest to spodni czy zewnętrzny element ubioru;

putnia 'złośliwie o tęgiej, grubej kobiecie'; znaczenie pierwotne: 'drewniane naczynie z klepek, o przekroju elipsowatym, z jednym uchem w wystającej klepce, lekko rozszerzające się ku górze, służące do noszenia wody’.

\subsubsection{Zanikanie leksemu}

Proces uwidacznia się, kiedy wyraz jest znany i używany przez osoby z najstarszego pokolenia. Następny etap to już tylko sama znajomość takiego wyrazu, bez jego używania (tak sie downo godało). Ostatecznie o występowaniu danego leksemu (lub znaczenia) zaświadcza dawna literatura lub dawne słowniki:

aśpit 'dachówka azbestowa, produkowana przed i po I wojnie światowej, mająca nazwę fabryczną ASBIT': Aśpit - podobne jak eternik, ale słabse (Kąś 2015, 133);

alwagon 'wóz pocztowy';

babica 'kobieta odbierająca dawniej poród w domu i opiekująca się matką i dzieckiem w pierwszych dniach po porodzie (zwykle bez wykształcenia medycznego, a mająca 
stosowną wiedzę nabytą od innych doświadczonych kobiet)': Były babice, a jakze, w Horklowyj, Knurowie. Ta w Knurowie była barz fajno. Jo jom wołała, choć zef jes z Horklowyj (synonimy, również znane tylko w najstarszym pokoleniu: baba, babcorka, babicula, babiorka, babka, krajbabka, mamcorka, pakułka; Kąś 2015, 145-146).

Wyrazy poświadczone tylko w dawnej literaturze i dawnych słownikach:

ajzbon 'kolej żelazna' (Janczy 1904, 67);

alarma 'hałas, harmider': Cozeście dzisiok alarme robiyt po nocý? (Zborowski 2009, 3);

apstrolok 'astronom, umiejący układać kalendarze' (Kantor 1907, 178).

\subsection{Leksem przestaje tworzyć rodzinę}

Gdy leksem nie ma powiązań słowotwórczych, jego dotychczasowe znaczenie nie jest wspierane wyrazami pokrewnymi. Następuje nie tylko rozmywanie się znaczenia, ale też sama forma staje się niestabilna:

fiśka 'podlotek';

pryncka 'z niechęcią o zarozumiałej, wystrojonej pannie'.

ślapytka 'chłop udający pana' (formy wariantywne: ślapietka, ślapetka, ślapytka, lapiytka.

Nie dziwi już zatem wypieranie podawanych wcześniej form tyniorka [ll tynina, tylina, tyniok], drandź [|| dranć, drandzia] przez ogólnopolską śtachetę.

Wskazane w niniejszym artykule uwarunkowania zmian w gwarowym systemie leksykalnym nie zamykają ich listy. Tutaj skupiono się na najistotniejszych, zdaniem autora, czynnikach wewnątrzsystemowych. Oprócz nich znane są też czynniki zewnątrzsystemowe, badane metodami socjolingwistycznymi (Kobus 2007).

\section{Biliografia}

Gutt-Mostowy J. (1998), Gwara o gwarze, Kraków.

Hodorowicz S.A. (2008), Dumacki, czyli myśli po góralsku dane, Nowy Targ.

Janczy W. (1904), Gwara Sromowiec Wyżnych, [w:] Materiały i Prace Komisji Językowej Akademii Umiejętności w Krakowie, t. I, s. 51-87.

Kantor J. (1907), Czarny Dunajec. Monografia etnograficzna, Kraków.

Karaś M. (1960), Wytyczne doboru wyrazów języka ogólnonarodowego do słownika gwar polskich, „Język Polski”, t. XL, s. 161-169, 262-281.

Kąś J. (1994), Interferencja leksykalna słownictwa gwarowego i ogólnopolskiego (na przykładzie gwar orawskich), Kraków.

Kąś J. (2015), Ilustrowany leksykon gwary i kultury podhalańskiej, t. I, Bukowina TatrzańskaNowy Sącz.

Kąś J. (2017), Ilustrowany leksykon gwary i kultury podhalańskiej, t. IV, Kraków.

Kobus J. (2007), Zróżnicowanie pokoleniowe wsi a problem rozwarstwienia języka jej mieszkańców - leksyka wielkopolska poczatku XXI wieku, „Gwary Dziś”, t. 4: Konteksty dialektologii, s. 307-314.

Kurek H. (2003), Przemiany leksyki gwarowej na Podkarpaciu, Kraków. 
Matlakowski W. (1901), Zdobienie i sprzęt ludu polskiego na Podhalu. Zarysy życia ludowego, Warszawa.

Pelcowa H. (2007), Nazwy sporadyczne i okazjonalne w opracowaniach gwarowych, „Gwary Dziś”, t. 4: Konteksty dialektologii, s. 177-185.

Wyderka B. (2007), O gwarowym stownictwie rzadkim, „Gwary Dziś”, t. 4: Konteksty dialektologii, s. 171-176.

Zborowski J. (2009), Stownik gwary Zakopanego i okolic opracowany i uzupetniony z materiałów Autora przez Zespót Instytutu Języka Polskiego Polskiej Akademii Nauk pod kierunkiem Joanny Okoniowej, Zakopane-Kraków. 